\title{
THE EFFECTIVENESS OF COMIC STRIPS USE TOWARDS READING SKILL OF THE SEVENTH GRADE STUDENTS OF SMP N 9 YOGYAKARTA IN THE ACADEMIC YEAR 2016/2017
}

\author{
Arifiana Tri Wulandari ${ }^{1}$, Soviyah ${ }^{2}$ \\ ${ }^{1}$ Universitas Ahmad Dahlan, Indonesia \\ ${ }^{1}$ arifianatri@gmail.com \\ ${ }^{2}$ Universitas Ahmad Dahlan, Indonesia \\ ${ }^{2}$ soviyah@pbi.uad.ac.id
}

\begin{abstract}
Teaching method is one of the aspects that must be given attention in a teaching learning process. The use of media becomes important strategy to get success in teaching learning process especially in teaching reading. The use of comic strips in teaching reading is expected to increase the students' achievement in reading. The aim of this research is to find out the effectiveness of comic strips in reading skill for students at the seventh grade of SMP N 9 Yogyakarta.

This research is an experimental research. This research was conducted in the SMP N 9 Yogyakarta on $5^{\text {th }}$ May until $19^{\text {th }}$ May, 2017. The population of this research was the seventh grade students, and the samples of this research were $7 \mathrm{~B}$ as the control class and $7 \mathrm{C}$ as the experimental class. The analysis technique used was quantitative. The instrument used in this research was pretest and posttest. The researcher used SPSS to analyze and calculate the data and to test the hypothesis.

The result of the calculation is $t_{0}>t_{\text {table }}$, it means that the Null Hypothesis $\left(\mathrm{H}_{\mathrm{o}}\right)$ is rejected and the Alternative Hypothesis $\left(\mathrm{H}_{\mathrm{a}}\right)$ is accepted. The mean of the pretest was 52.80, and the mean of the posttest was 75.45. Based on the result of this research, it showed that the use of comic strips in teaching reading was effective.
\end{abstract}

Keywords: teaching reading, reading skill, comic strips

\section{INTRODUCTION}

1.1 Background of Study

Reading is a process to find the information from a text. Reading is also a good way to increase the ability of English. From reading, someone can get new information that can also deliver the information to others. The aims of reading are to get details or facts information, to get the main ideas, to compare or contrast two things, etc. There are some benefits of reading, they are to increase the vocabulary, to understand the structure, to improve the pronunciation, to understand about English clearly, and to increase the knowledge. To improve students' skill reading, they can improve with skim and scan. According to Harmer (2010: 101), the students are perfectly capable in reading for detailed comprehension, whether this entails looking for detailed information or picking out particular examples of language use.

To improve the students' abilities about English, the teacher can use media. Media can help teachers to convey their knowledge to the primary school student. Using media can also make the students enjoy the lesson. Media can improve their performance, and they will learn more especially in learning English.

According to PIRLS (Progress in International Reading Literacy Study) research, it shows that the children of Indonesia are at forty first position from forty five country of the world in reading. There are some reasons why the abilities of reading in Indonesia are low especially in English reading. The first reason is the English understanding of students is low. The second, some students think that 
English lesson is difficult. The third, the vocabularies of students are low. The fourth, the students didn't know to use grammar correctly. The last, the using media are low.

This study would present a reading strategy to junior high school students. The teaching strategy uses Comic Strips. Comic Strips are media which are like comic, but it consists of some pictures. Although comic strips only consists some pictures, the contents of comic strips provide an idea. It also shows the recently event or the new issues. By providing a media in teaching reading to junior high school students, the researcher hoped that it would make them felt something pleasant and felt it different from what they used to get in the class. By the activity, the students were given an opportunity to express their emotion, and feeling when they were involved in it. Based on the explanation above, the researcher assumed that the use of comic strip was one of good and effective ways to teach and to motivate them to study.

1.2 Formulation of the Problem

Based on the background of study, the formulation of the problem can be formulated "Is comic strips effective to teach reading skill for students of seventh grade of SMPN 9 Yogyakarta?"

1.3 Objective of the Study

In line with the problem formulation, the objective of the study can be elaborated "To find out the effectiveness of Comic Strips in reading skill for students at the seventh grade of SMPN 9 Yogyakarta".

\section{LITERATURE REVIEW}

2.1 Definition of Reading

There are many experts who discuss about the definition of reading. Snow (2002:15) says that a reading activity involves one or more purpose, some operations to process the text at hand, and the consequences of performing the activity. The purpose is influenced by a cluster of motivational variables, including interest and prior knowledge. Smith (2004:2) says "reading is properly employed for all manner of activities when we endeavor to make sense of circumstances; its original meaning was interpretation. Reading, when employed to refer to interpretation of a piece of writing, is just a special use of the term".

2.2 Reading Principles

Teaching reading process will be successful if the teachers pay deep attention on the principles of reading. According to Harmer (2007: 101), there are six principles. They are:

1) Encourage students to read as often and as much as possible

Encourage the students to read extensively as well as - if not more than intensively. It is a good idea to discuss this principle with students.

2) Students need to be engaged with what they are reading

Try to help the students get as much pleasure from it as possible. During the lesson, the teachers will do our best to ensure that the students are engaged with the topic of a reading text and the activities they are asked to do while dealing with it.

3) Encourage students to respond to the content of a text (and explore their feelings about it), not just concentrate on its construction

The students should be allowed to show their feelings about the topic -thus provoking personal engagement with it and the language. 
4) Prediction is a major factor in reading

Book covers give us a clue about what is in the book; photographs and headlines hint at what articles are about.

5) Match the task to the topic when using intensive reading texts

As the teachers need to choose good reading tasks - the right kind of questions, appropriate activities before during and after reading, and useful study exploitation, etc.

6) Good teachers exploit reading texts to the full

Good teachers integrate the reading text into interesting lesson sequences, using the topic for discussion and further tasks, using the language for study and then activation and using a range of activities to bring the text to life.

\subsection{Reading Skills}

Reading has some skills which is the important aspects. The students know what they are. According to Harmer (2007: 100-101), there are three skills in reading:

1) Scan

Students need to be able to scan the text for particular bits of information they are searching for. This skill means that they do not have to read every word and line; on the contrary, such an approach would stop them scanning successfully.

2) Skim

Students also need to be able to skim a text - as if they were casting their eyes over its surface - to get a general idea of what it is about. The students don't identify the general idea because they are concentrating too hard on specifics.

3) Reading for detailed comprehension

Whether this entails looking for detailed information or picking out particular examples of language use, should be seen by students as something very different from the skills mentioned above.

\subsection{Comic Strips}

There are many ways to make the lesson of English fun and enjoyable. One of the ways is the using media. Now, the development of media is increasing. The teachers can use it to support the learning. Comic is one of the media which can be used by the teacher. According to Eisner (1985: 7), comic communicates in a language that relies on a visual experience common to both creator and audience. Comic employs a series of repetitive images and recognizable symbols.

In addition, comic strips must contain images, word that make the students enjoy when they read. Comic strip is one of the techniques which can be used in teaching reading. It can be useful for the teachers and the students.

\section{METHODS}

This research was conducted in the SMP N 9 Yogyakarta, and the time of this research was conducted on $5^{\text {th }}$ May until $19^{\text {th }}$ May, 2017. The population of the research was the seventh grade students of SMP N 9 Yogyakarta. To conduct this research, the researcher took $7 \mathrm{~B}$ and $7 \mathrm{C}$ class. $7 \mathrm{~B}$ was used as the control class, and 7C was used as the experimental class. The researcher used Random Sampling.

This research used an experimental research. The design of this research used the two-group design which employed as experimental and control groups. This design started with pre-test, treatment and post-test which involved experiment and control groups. 
The data were taken from pretest and posttest. The pretest was done before the treatments, and the posttest was done after the treatments.

To collect the data, the researcher used quantitative data. The quantitative data were taken by pre-test and post-test. The test was reading test which was formed in multiple choices, and the numbers of the test were 10 . The steps began with the pretest, treatments and post-test. The procedures that used in this experimental research as follows:

a. Pretest

The pretest was done before the learning process. Students in experimental and control classes were asked to do a test about Descriptive text.

b. Treatment

In the treatment, the researcher conducted teaching-learning activity with the students both of experimental and control classes in fourth meetings. In the first meeting of treatment, the researcher explained about descriptive text. In the next third meetings, the researcher asked the students to answer some questions about descriptive text by using different media, and also different comic strips for students in experimental class specially.

c. Posttest

The last was posttest. It was done to know the progression between experimental and control classes after the teacher gave treatments to the students. In the last meeting, the researcher gave the test to the students in the both of classes. Students in experimental class were asked to do the test by using comic strips. Meanwhile, students in control class were asked to do the test without using comic strips.

To analyze the data, the test used to find out the effectiveness of comic strips in teaching reading. The researcher used T-test, and it was calculated by SPSS. The researcher used Independent Sample Test of SPSS.

\section{FINDINGS AND DISCUSSION}

Based on the validity and reliability test, the instruments were categorized valid and reliable. The analysis of pretest and posttest used independent sample test. The mean of experimental class in pretest was 52.80, and the mean of control class in pretest was 53. The mean of experimental class in posttest was 75.45, and the mean of control class in posttest was 75 .

The data of the students' score was analyzed by using SPSS. The researcher used T-test formula to find the empirical evidence statistically and to make the testing of hypothesis. By using SPSS, the researcher calculated the data easily. The calculation of the data is described into table, and it is categorized into pretest and posttest.

Before the researcher calculated the data, the researcher showed the homogeneity and normality of the data. The homogeneity of the data was 0.124 , and the value was higher than 0.05 . It meant that the data was homogeneous. The normality of the data was 0.189 , and the value was higher than 0.05 . It meant that the data was normal. 
The following tables 1 and 2 described the pretest and posttest calculation:

Table 1: Independent Samples Pretest

\begin{tabular}{|c|c|c|c|c|c|c|c|c|c|c|}
\hline & & \multicolumn{2}{|c|}{$\begin{array}{l}\text { Levene's } \\
\text { Test for } \\
\text { Equality of } \\
\text { Variances } \\
\end{array}$} & \multicolumn{7}{|c|}{ t-test for Equality of Means } \\
\hline & & & & & & & & & $\begin{array}{r}95 \% \mathrm{Co} \\
\text { Interva } \\
\text { Diffe }\end{array}$ & $\begin{array}{l}\text { fidence } \\
\text { of the } \\
\text { ence }\end{array}$ \\
\hline & & $\mathrm{F}$ & Sig. & $\mathrm{t}$ & $\mathrm{df}$ & $\begin{array}{c}\text { Sig. } \\
(2- \\
\text { tailed } \\
)\end{array}$ & $\begin{array}{c}\text { Mean } \\
\text { Differenc } \\
\mathrm{e}\end{array}$ & $\begin{array}{c}\text { Std. Error } \\
\text { Differenc } \\
\text { e }\end{array}$ & Lower & Upper \\
\hline $\begin{array}{l}\text { Pr } \\
\text { e } \\
\text { tes } \\
\text { t }\end{array}$ & $\begin{array}{l}\text { Equal } \\
\text { variance } \\
\mathrm{s} \\
\text { assumed }\end{array}$ & $\begin{array}{r}1.06 \\
0\end{array}$ & $\begin{array}{r}.30 \\
7\end{array}$ & $\begin{array}{r}- \\
.05 \\
0\end{array}$ & 65 & .960 & -.21390 & 4.26071 & $\begin{array}{r}- \\
8.7231 \\
4\end{array}$ & $\begin{array}{r}8.2953 \\
3\end{array}$ \\
\hline & $\begin{array}{l}\text { Equal } \\
\text { variance } \\
\text { s not } \\
\text { assumed }\end{array}$ & & & $\begin{array}{r}- \\
.05 \\
0\end{array}$ & $\begin{array}{r}58.05 \\
8\end{array}$ & .960 & -.21390 & 4.23663 & $\begin{array}{r}- \\
8.6942 \\
6\end{array}$ & $\begin{array}{r}8.2664 \\
6\end{array}$ \\
\hline
\end{tabular}

For the analysis of $\mathrm{F}$ test, it showed that the $\mathrm{F}$ value was 1.060 with significance level, 0.307. Because the value was higher than 0.05 it meant that the data was homogeneous. For the analysis of the $\mathrm{T}$ test, it showed that the $\mathrm{T}$ value was -0.050 with significance level, 0.960 . Because the value was lower than 0.05 it meant that the mean of both classes was not homogeneous.

Table 2: Independent Samples Posttest

\begin{tabular}{|c|c|c|c|c|c|c|c|c|c|c|}
\hline & & \multicolumn{2}{|c|}{$\begin{array}{l}\text { Levene's } \\
\text { Test for } \\
\text { Equality of } \\
\text { Variances }\end{array}$} & \multicolumn{7}{|c|}{ t-test for Equality of Means } \\
\hline & & & & & & & & & $\begin{array}{r}95 \% \text { Co } \\
\text { Interva } \\
\text { Diffe }\end{array}$ & $\begin{array}{l}\text { fidence } \\
\text { of the } \\
\text { ence }\end{array}$ \\
\hline & & $\mathrm{F}$ & $\begin{array}{c}\text { Sig } \\
.\end{array}$ & $\mathrm{t}$ & $\mathrm{df}$ & $\begin{array}{c}\text { Sig. } \\
(2- \\
\text { tailed } \\
\quad)\end{array}$ & $\begin{array}{c}\text { Mean } \\
\text { Differenc } \\
\mathrm{e}\end{array}$ & $\begin{array}{c}\text { Std. } \\
\text { Error } \\
\text { Differenc } \\
\mathrm{e}\end{array}$ & Lower & Upper \\
\hline $\begin{array}{l}\text { Postte } \\
\text { st }\end{array}$ & $\begin{array}{l}\text { Equal } \\
\text { variance } \\
\text { s } \\
\text { assume } \\
\text { d }\end{array}$ & $\begin{array}{r}2.17 \\
2\end{array}$ & $\begin{array}{r}.14 \\
5\end{array}$ & $\begin{array}{r}.22 \\
1\end{array}$ & 65 & .826 & .74866 & 3.38403 & $\begin{array}{r}- \\
6.0097 \\
2\end{array}$ & $\begin{array}{r}7.5070 \\
4\end{array}$ \\
\hline & $\begin{array}{l}\text { Equal } \\
\text { variance } \\
\text { s not } \\
\text { assume } \\
\text { d }\end{array}$ & & & $\begin{array}{r}.22 \\
2\end{array}$ & $\begin{array}{r}61.24 \\
0\end{array}$ & .825 & .74866 & 3.36986 & $\begin{array}{r}- \\
5.9892 \\
5\end{array}$ & $\begin{array}{r}7.4865 \\
8\end{array}$ \\
\hline
\end{tabular}

The $\mathrm{F}$ value was 2.172 with significance level 0.145 . The $\mathrm{T}$ value of experimental class was 0.221 with significance level, 0.826 , and $\mathrm{T}$ value of control class was 0.222 with significance level 0.825 . 
In sum, the result of the data showed that $t_{v a l u e}>t_{\text {table. It proved that the null }}$ hypothesis $\left(\mathrm{H}_{\mathrm{o}}\right)$ is rejected and the alternative hypothesis $\left(\mathrm{H}_{\mathrm{a}}\right)$ is accepted. There is significant difference between the students' score in reading skill by using comic strips and the students' score in reading skill without using comic strips. This is proved by the mean of the control and experimental classes which was different. The students' posttest score of experimental class increased higher.

The result of the research showed that the students of experimental group had better achievement than students of control group did. It is simply concluded that null hypothesis $\left(\mathrm{H}_{\mathrm{o}}\right)$ "There is no significant difference between the students' score in reading by using comic strips and the students' score in reading without using comic strips" is rejected. Meanwhile, the alternative hypothesis $\left(\mathrm{H}_{\mathrm{a}}\right)$ "There is significant difference between the students' score in reading by using comic strips and the students' score in reading without using comic strips" is accepted.

The result above supports what Ali (2013) revealed. According to Ali (2013), all students with a comic strip effect, regardless of proficiency and text level, performed better than the ones without the comic strip.

Another evidence which supports the result of the research was the one done by Liu (2004) proved that using comic strips with the high-level text might have prevented the high-level students from exploring the text's complexities as indicated in the recall protocols.

To summarize, based on the result of the research which is supported by some relevant studies, it can be said comic strips is effective to use in teaching reading especially to junior high school students.

\section{CONCLUSION}

Based on the result of the research, using comic strips in teaching reading can increase the student's achievement. It can be concluded that the use of comic strips in teaching reading is effective. It can be seen from the data of students' score of the experimental class that the students who learn reading by using comic strips has a significant difference, which is showed by the reading score in the posttest. The experimental class, using comic strips got higher score than those of the control class. It means that there is a difference in the students' achievement taught by using comic strips and the students' achievement taught without using comic strips. Therefore, comic strips is appropriate to use teaching reading.

\section{REFERENCES}

Arikunto, Suharsimi. (2010). Prosedur Penelitian Suatu Pendekatan Praktik. Jakarta: Rineka Cipta.

Brown, Douglas. (2001). Teaching by Principle: An Interactive Approach to Language Pedagogy. San Francisco: Longman.

Brown, Douglas. (2004). Language Assessment: Principle \& Classroom Practice. San Francisco: Longman.

Calmorin, Laurentina Paler, \& Melchor, A. Calmorin. (2007). Research Method and Thesis Writing Second Edition. Manila: REX Book Store.

Eisner, Will. (1985). Comics \& Sequential Art. Florida: Poorhouse Press.

Flynn, Naomi, \& Rhona, Stainthrop. (2006). The Learning and Teaching of Reading and Writing. Cornwall: Whurr Publisher Limited.

Harmer, Jeremy. (2007). How to Teach English. Oxford: Pearson Education Limited. 
Harmer, Jeremy. (2010). The Practice of English Language Teaching. Oxford: Pearson Education Limited.

Johnson, Andrew P. (2008). Teaching Reading and Writing: A Guidebook for Tutoring and Remediating Students. Lanham: Rowman and Littlefield Education.

Liu, Jun. (2004). Effect of Comic Strips on L2 Learners' Reading Comprehension. Arizona: TESOL QUARTERLY. Vol. 38, No. 2.

Merc, Ali. (2013). The Effect of Comic Strips on EFL Reading Comprehension. Eskisehir: International Journal on New Trends in Education and Their Implications. Vol. 4, No. 5

Smith, Frank. (2004). Understanding Reading: A Psycholinguistic Analysis of Reading and Learning to Read. London: Lawrence Erlbaum Associates.

Snow, Catherine. (2002). Reading for Understanding: Toward an $R \& D$ Program in Reading Comprehension. Santa Monica: RAND.

Sugiyono. (2010). Metode Penelitian Pendidikan. Bandung: Alfabeta.

Other Reference:

http://jempolbayek.blogspot.co.id/2015/11/uji-hipotesis-uji-parsial-atau-ujit.html?m=1 